\title{
子どもの精緻的学習に及ぼす文脈に よる意味的限定の效果
}

\author{
豊 田弘 司*
}

学校の教授 (授業) 場面では, 教師によって知識や概 念に関する解説が行われ，児童生徒は様々な文脈の中で 情報を処理することが求められる。そこでは知識や概念 そのものを機械的に学習するのではなく, 関連した多様 な情報処理を行うことによって, 結果的に知識や概念に 関する学習が成立する。したがって, ここで成立する学 習は, 意図学習というよりもむしろ偶発学習に近いもの とみなされる(北尾・金子，1981)。それ故，教授場面に おいて, 児童生徒が教授されるべき概念を効果的に学習 するために, どのような付加的な情報, すなわち文脈が 呈示されればよいかということが, 極めて重要な課題で あるといえる。

ところで, 最近の記憶研究では, Craik \& Lockhart (1972) による処理水準説が有力である。この処理水準説 によれば, 深い処理すなわち意味的処理の方が, 浅い処 理すなわち非意味的処理よりも優れた記憶成績をもたら すといら予想が成り立ち, この予想は多くの研究 (Hyde, 1973 ; Hyde \& Jenkins, 1969 etc.) によって支持され てきた。しかし，同じ意味的処理をした場合であっても， その処理の程度によって記憶成績に差が生じる場合があ り，単に処理の水準という概念のみでは説明不可能とな った。たとえば，枠組み文に記銘語がうまくあてはまる か否かを判断する方向ゔけ課題を行った場合, “Yes”と 答えた方が “No”と答えた場合よりも記憶成績が良くな るという場合である (Craik \& Tulving, 1975 etc.)。 そこで, 同じ意味的処理であっても情報処理の程度が異 なるという考え方から, 処理の水準を補う概念として, 符号化の拡がり (Craik \& Tulving, 1975), 処理の拡が り (Kolers, 1975), 意味的処理の量 (Johnson-Laird \& Bethell-Fox, 1978; Johnson-Laird, Gibbs \& DeMowbray, 1978) といった新しい概念が提出されてきた。こ れらの新しい概念をまとめて, 精緻化 (elaboration) と 呼ぶとすると，そこでは個々の語の精緻化は呈示される 文脈によって異なり，それが記憶成績に反映するという

* 奈良保育学院
予言が成り立つ。したがって, 上述した教授場面での重 要な課題, すなわち児童生徒に呈示すべき文脈について の理論的枠組みが与えられると考えられ，このことは, 北尾（1982）においても指摘されている。

たとえば, Craik \& Tulving (1975) は, 記銘語が枠 組み文に適合するか否かを判断させる方向づけ課題にお いて, その文の長さを変えることによって, 複雑性を操 作している。その結果, 枠組み文が複雑である（長い） 場合の方が, 単純な（短い）場合よりも記憶成績の優れ ることが明らかにされた。また，わが国においても，北 尾（1982）が単純な枠組み文の場合（たとえば，記銘語 が“こまく”である場合，耳の中に_があります）と 多様な枠組み文の場合（耳の中に_という，音を感じ るのに必要な, うすいまくがあります) を比較し, 後者 の方が記憶成績の優れることを見いだしている。このよ うな研究を総括してみると, 記憶成績は枠組み文の長 さ，すなわち記銘語に付加される情報の量に左右される ことになる。言いかえれば, 有効な精維化は記銘語に付 加される情報量によって決定されるということができ る。

しかし, 有効な精徽化には付加される情報の量のみが 決定的な要因ではないことを示す研究もある。たとえば, Stein, Morris, \& Bransford (1978) は, 以下に示すよう な 3 種類の枠組み文間の記憶成績を比較している。すな わち, 記銘語“slow” に対して, “The diamond was too expensive for the ___ man. (以下A文之略す)”, "The diamond was too expensive for the __. man who was fired from his job. (以下B文上略す)”, お よび "The diamond was too expensive for the man to hand down to his son. (以下C文と略す)” と いう3 文である。被験者は記銘語を枠組み文に入れた際 の文の理解度を 5 段階で評定するという方向づけ課題を 行い, その後, 枠組み文を手がかりとする手がかり再生 を求められた。有効な精政化が記銘語に付加される情報 量によって決定されるのであれば, 文の長さが一番短い A文での成績が最も悪くなるはずである。しかし, 結果 
はB文での成績が最も良く, 次に A文が続き, C文での 成績が一番悪くなったのである。彼らは,この結果から 有効な精緻化は単に付加される情報量によって規定され ず，情報の質に依存するという結論を示している。さら に，C文での成績が最も悪かったことについて，C文で は記銘語と被験者のもつ記銘語に関する知識を関連づけ て利用するための援助が与えられていないと述べている。 すなわち，C文は記銘語の意味理解を促す知識を活性化 させるような援助を与えないとしているのである。

彼らは, 枠組み文により活性化される被験者の知識面 を強調したが, 彼らの研究から明らかに言及できること は, 枠組み文と記銘語の関係が精緻化にとって重要な要 因となるということであろう。C文では，何故記銘語が その文の中において適切(relevant) であるのかを明確に するために必要な援助が提供されていないと述べられて いる。これは，言いかえるならば，枠組み文によって， 記銘語が “slow“である理由の説明がなされていないと 言えるであろう。より具体的にいうならば， B 文では “who was fired from his iob”という部分から, 記銘 語 “slow”がかなり強く規定される。すなわち“slow”の 代わりとなる語の数沙ないといえる。一方, C文では “to hand down to his son”という部分から“slow”を 規定することは難しい。すなわち“slow” の代わりとな る語の数は多いといえるであろう。これは, 枠組み文, すなわち文脈のもつ記銘語に対する意味的限定の程度が 異なると考えることができる。要するに, 意味的限定が 強い枠組み文（B文）の方が, 弱い文（C文）よりも有 効な精緻化がなされると考えられるのである。

ところで, 従来の文脈による意味的限定を扱った研究 には, Hall \& Crown(1970) がある。彼らは, 記銘語を 呈示する際に 2 種類の文を設け, 両者の再認テストでの 虚再認（“なかった”語に対して誤って“あった”とする 反応)の分析を行っている。たとえば, 記銘語が “hot” の場合, “It was a day.”および “It was a

fire.”となる。前者（交換可能文）では，記銘語 “hot” からの連想語“cold”を“hot”の代わりに入れても文とし て成り立つが, 後者(交換不可能文)では成り立たない。 結果は，記銘語が交換可能文で呈示された場合には連想 語に対して虚再認が生じたが，交換不可能文では文脈に よる意味的限定のために, 連想語に対する虚再認が生じ なかったのである。同様に，わが国においても豊田（19 84）が，交換可能文および交換不可能文を用いて文脈に よる意味的限定を見いだしている。これらの研究より, 交換不可能文が交換可能文よりも意味的限定が強い文で あることは明らかである。
しかし,これらの研究では意味的限定にのみ関心があ り，そのために精緻化を扱った研究と異なり意図学習事 態での検討を行っていた。それ故，枠組み文によって生 じる記銘語そのものの精緻化の程度については, 全く検 討されなかったわけである。また，従来の精緻化に関す る研究でも，記銘語の精緻化に及ぼす意味的限定の効果 についてはほほとんど注目されなかった。ただ，上述し た Stein らの研究において，ある程度記銘語の精緻化に とって意味的限定が重要であることは推察される。しか し, 彼らの研究では, 意味的限定が明確に定義されてい るわけではない。それ故，枠組み文の記銘語に対する意 味的限定が精緻化に対してどのような効果をもつのかと いう問題は，いまだ不明のままである。

そこで, 本研究では, 枠組み文の記銘語に対する意味 的限定の程度を, 記銘語とその連想語との交換可能（不 可能）性によって明確に操作し, 記銘語の精緻化に及ぼ す効果を検討することを第 1 の目的とした。そして，第 1 の実験仮説としては, 記銘語の偶発記憶成績は意味的 限定の強い交換不可能文を枠組み文とする方が，交換可 能文を枠組み文とするよりも良いであろうという仮説が 設定された。

他方, 豊田 (1984) では, 意味的限定における発達的 側面を明らかにしている。すなわち，小学 6 年生では交 換不可能文による意味的限定が生じるが， 2 年生では生 じないことを見いだしたのである。これは，2 年生が発 達上，まだ文脈をとらえて符号化する水準まで達してい ないことを意味している。この発達的な違いは, 教授場 面において呈示すべき文脈を検討する上で重要である。 というのは，ある年龄の子どもには有効な文脈であって も，他の年齢の子どもにとっては有効でないという可能 性が考えられるからである。豊田（1984）によって見 いだされた発達差を考慮すると， 2 年生では第 1 の実験 仮説は支持されないと予想される。というのは，2 年生 ではまだ枠組み文のもつ文脈をとらえて符号化する水準 にまで達していないからである。そこで, 本研究の第 2 の目的は, 記録語の精緻化に及ぼす意味的限定の効果を 発達的に検討することであった。そして, 第 2 の実験仮 説として, 文脈をとらえて符号化できない 2 年生では, 交換可能文と交換不可能文の間の偶発記憶成績には差が ないであろらが, 文脈をとらえた符号化のできる 6 年生 においては, 交換不可能文が交換可能文よりも成績は良 いであろうという仮説を設定した。

\section{実 験 I}

目的上述の第 1 の実験仮説を検討することを目的と 
して，以下に述べる実験が企てられた。

\section{方 法}

実験計画 枠組み文の型を被験者内要因とする 1 要因 の要因計画であり, 交換可能文, 交換不可能文および不 適合文の 3 文型を含んでいた。

被験者 看護学校の学生 40 名が実験に参加した。これ らの学生の平均年齢は，21歳 0 か月であった。

材料 記銘語および再認テストで用いられた語は TABLE 1 亿示されている。これらの語は，ひらがな $3 \sim 5$ 文字から成るよく知られた語であり, 清水 (1980) の連 想表から選ばれた。TABLE 1 のAの欄に示されている 10 語が再認テストにおける標的刺激 (target) として用い られた。再認テストでの追加刺激 (distractor) としては, TABLE 1のBおよびCの闌に示した記銘語からの連想語 が20語とどの記銘語とも連想関倸のない語（無関連語） が10語用いられた。

方向づけ課題では，上述の記銘語が枠組み文に適合す る程度を評定させたのであるが，そのための枠組み文も 作成された。TABLE 1 のBおよびCの闌に示された記 銘語の各々に対して，その連想語と交換可能な文および 交換不可能な文を 1 文ずつ作成した。ただし，この際に 1 つの記銘語に対応する両文の長さがほぼ等しくなるよ らに，文字数の差は 2 文字以内にそろえた。これらの文 例は，対応する記銘語およびその連想語とともに， TABLE 2 亿示してある。また，Aの欄に示された記銘語に 対しても，枠組み文が 1 文ずつ作成された。ただし，こ れらの文注記銘語を文中に入れた場合，文として成り立 たない不適合文であった。

方向づけの課題で用いられた評定用紙は B 6 判の大き さで， 1 枚に 1 語ずつ記銘語が上部の中央に，そしてそ の下に枠組み文と評定尺度が印刷されていた。この評定 尺度は，記銘語を枠組み文の中に入れた際に適合する程 度を, “あてはまらない”から“非常にうまくあてはま る”までの 5 段階で評定させるためのものであった。 2 つの評定リストが用意された。すなわち，リスト 1 は， TABLE 1のBの闌の記銘語に対応する枠組み文として交 換可能文を用い，Cの欄の記銘語に対しては交換不可能 文を用いた。一方リスト 2 はその逆であった。なお， Aの欄の記銘語に対しては，両リストともに不適合文を 枠組み文として用いた。したがって，1リストは枠組み 文として，交換可能文，交換不可能文および不適合文を 10文ずつ含むことになる。さらに両リストは，リストの 最初と最後にバッファー(buffer) 語とそれの枠組み文が つけ加えられ，表紙をつけた小冊子にされた。
TABLE 1 本研究で用いられた語

\begin{tabular}{|c|c|c|c|c|c|c|}
\hline 記 & 銘 & 語 & 再誈 & 忍テストご & 男いら & た噖 \\
\hline A & $B^{\circ}$ & C & A & Bつ溥想語 & Cひ）浬想語 & 無䦔漸琵 \\
\hline あふない & 沬しる & きたない & ぶない & あるく & 声れい & せんろ \\
\hline あて心 & $<b w$ & たかい & あち & あかるい & $u<w$ & 万うか \\
\hline わるい & 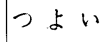 & つめたい & かるい & 上わ & あつい & たんほ \\
\hline はたらく & かなしい & はがき & はならく & 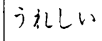 & てがみ & $\left(\begin{array}{lll}u & <\end{array}\right)$ \\
\hline にげる & $=と ゙ も$ & ながい & にげる & おとな & 邓しかい & となり \\
\hline しゃしル & しょうじき & はやい & しャしん & う天つき & $\hbar \div い$ & i) $ん こ=$ \\
\hline $0<る$ & かおもち & $\therefore$ がい & $0<3$ & びんぼう & 交まい & $<3$ \\
\hline や文む & 放えさん & せんせい & やすむ & にいきル & せいと & まいにち \\
\hline$j=<$ & $<3 い$ & 扮方る & $j=\check{<}$ & しろい & はじまる & かるい \\
\hline$=\hbar \omega$ & おがきん & 1 いさっ & $=$ h & おじさん & どうばう & お上こ \\
\hline
\end{tabular}

TABLE 2 交換可能文および交換不可能文の例

\begin{tabular}{|c|c|c|c|}
\hline 就销請 & 渾想清 & 父 换 而能 文 & 父换不可能支 \\
\hline 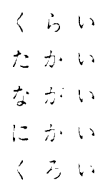 & 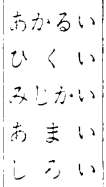 & 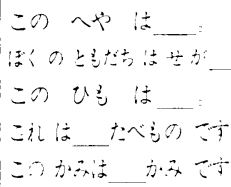 & 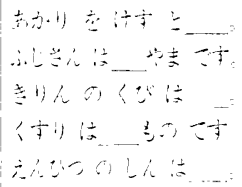 \\
\hline
\end{tabular}

自由再生テストで用いられた用紙は，B 6 判で，上部 に氏名を記入する闌が設けてあり，その下に再生した語 を筆答するようになっていた。再認テスト用紙は，B 5 判の大きさで 40 語が 2 列に渡って 20 語ずつ印刷されてい た。これらの語は, 上述したように, 標的刺激が10語, 追加刺激としての連想語が 20 語および無関連語が 10 語で あり，ランダムに配列してあった。なお，これらの語の 右横には，6段階の確信度評定尺度が印刷されていた。 また，方向づけ（評定）課題と自由再生テストの間に挿 入課題を行うが，そのための用紙も用意された。この用 紙はB 4 判の大きさで, 有意味な文字配列および無意味 な文字配列が印刷されているものであった。

手続 実験は偶発学習実験の手続を採用し, 被験者の 所属する看護学校の一室で集団的に実施された。まず， 被験者の半数（20名）にリスト 1 , 残り半数にリスト 2 の小冊子を配布した。そして, 評定用紙の上部に印刷さ れた語（記銘語）を下の文（枠組み文）に入れた際に適 合する程度を 5 段階で評定するように，例を用いて課題 の進め方についての教示を与えた。被験者が課題の進め 方について理解したことを確認した後，実験者の合図に 従って 1 ページにつき $10 \mathrm{sec}$. で評定させた。評定終了後, 上述の用紙を配布して $3 \mathrm{~min}$. 間の挿入課題を行った。こ の課題は, 用紙に印刷された文字列の中から 3 文字以上 の名詞を見つけだして丸印をつけるものであった。 
雨入課題終了後, 用紙を配布し，筆答による自由再生テ ストを $10 \mathrm{~min}$. ，さら汇再認テストを $5 \mathrm{~min}$. 間実施した。 再認テストでは，用紙に印刷された各語に対する記憶の 確信度に基づき，6段階のいずれかに丸印をつけるよう に求めた。

\section{結 果}

方向づけ課題で用いられた評定用紙をチェックしたと ころ, どの被験者にも記入もれはなく, 逸脱した反応も 認められなかった。このことから, 被験者が方向ゔけ課 題を適切に行っているといえる。また, 実験後, 記憶の 意図を持った者に挙手を求めたが挙手はなく，全員が記 憶の意図を持たなかったことが明らかにされた。

正再生率 自由再生テストにおける正再生率は, FIG. 1 に示してある。正再生率を角変換 $\left(\mathrm{x}^{\prime}=\sin ^{-1} \sqrt{\mathrm{P}}\right) し て$, 枠組み文の型を被験者内要因とする分散分析を行ったと ころ, 枠組み文型の主効果 $(\mathrm{F}=36.45, \mathrm{df}=2$ Ł $78, \mathrm{P}<$ .01）が有意であった。Tukey 法による下位検定を行っ たところ，交換不可能文を枠組み文とする語の正再生率 が交換可能文を枠組み文とする語のそれよりも $5 \%$ 水準 で高く，不適合文を枠組み文とする語のそれよりも $1 \%$ 水準で高かった。また，交換可能文を枠組み文とする語 の正再生率も不適合文を枠組み文とする語のそれよりも 高かった $(\mathrm{P}<.01)$ 。

虚再認得点 再認テストにおいて6段階確信度評定を 行ったが，“確かになかった”から“確かにあった”まで の各段階に対応させて 0 から 5 点の確信度得点を割りあ てた。交換可能文を枠組み文とする記銘語からの連想語 に対する確信度得点を交換可能虚再認得点と呼び，交換 不可能文を枠組み文とする記銘語の場合のそれを交換不

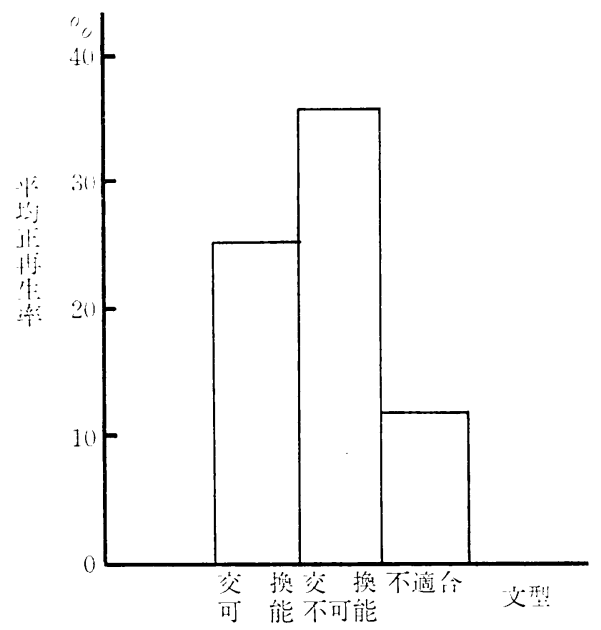

FIG. 1 枠組み文型ごとの正再生率

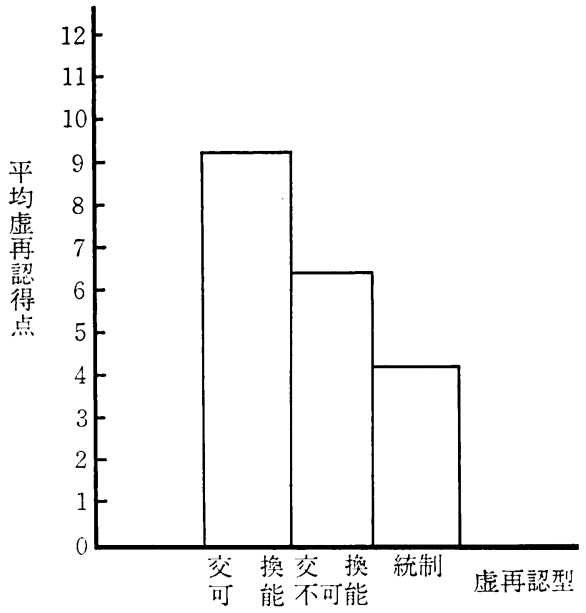

FIG. 2 虚再認型ごとの虚再認得点

可能虚再認得点と呼び，記銘語と無関連な語に対するそ れを統制虚再認得点と呼んで，それぞれの得点をカウン トした。この虚再認得点の平均值は, FIG. 2 に示してあ る。虚再認型を被験者内要因とする分散分析を行ったと ころ, 虚再認型の主効果 $(\mathrm{F}=14.61, \mathrm{df}=2$ と $78, \mathrm{P}<$ .01）が有意であった。Tukey 法による下位検定の結果, 交換可能虚再認得点は交換不可能虚再認得点よりも $5 \%$ 水準で高く, 統制虚再認得点よりも $1 \%$ 水準で高かっ た。しかし，交換不可能虚認得点と統制虚再認得点の間 には有意な差は認められなかった。なお, 標的刺激に対 する確信度得点, 寸なわちヒット得点の平均值は, 27.18 (SD : 9.91) であった。

\section{考・察}

交換不可能文を枠組み文とする語の方が，交換可能文 を枠組み文とする語よりも再生成績が優れていたことか ら, 第 1 の実験仮説は支持された。このことから, 有効 な精緻化は単に記銘語に付加される情報量によって決定 されるものではなく，情報の質によって決定されるとい えるであろう。また, 再認テストでの交換可能虚再認得 点が交換不可能虚再認得点よりも高かったことは, 被験 者が枠組み文のもつ文脈をとらえて記銘語を符号化した ことにより意味的限定が生じたことを示している。した がって，有効な精緻化へ導く情報の質を規定する 1 つの 条件は，その情報が記銘語に対して意味的限定性をもっ ていることであるといえる。

Stein ら (1978) の解釈に従えば, 本実験の結果は次の ように考えることができる。すなわち，交換不可能文を 枠組み文とする場合には，記銘語と被験者自身の知識を 関連づける援助が提供されたことになり，そのために記 
銘語に関連する知識が活性化したのである。ただ，彼ら の研究では, 枠組み文を再生時の手がかりとして用いる 手がかり再生事態であったので，枠組み文から記銘語を 推測 (guessing)することが可能であった。それ故, 純粋 に記銘語自体の精緻化が結果に反映されているか否かに 関しては疑問が残ると思われた。しかし，本実験で記銘 語のみの再生を求める自由再生事態であっても同様の結 果を得たことから，精緻化にとって枠組み文と記銘語の 関係が重要な要因であることが改めて確証されたといえ る。

ところで, Anderson \& Reder (1979) は, 記銘語を 直接検索することができない場合に記銘語に付加された 情報を検索し，その後でその情報を手がかりとして記銘 語を検索することができると述べている。したがって， 記銘語に情報を付加すればするほど検索ルートが増すこ とになるので, 検索が有利になり記憶成績が良くなるの である。この考え方は, 精緻化が付加される情報の量に よって決定されることの 1 つの主要な説明である。しか し,この考え方によれば, 付加される情報の量が等しい 場合には, 検索ルートの数が変わらないので記憶成績に 差は生じないことになる。それ故, 本実験の交換可能文 と交換不可能文間の記憶成績の差のように，付加される 情報量が等しい（枠組み文の長さが等しい）場合に見ら れる記憶成績の差を説明できないのである。

そこで, Anderson らの考えにさらに1つの要因を付 け加えることを考えてみた。その要因とは, 検索手がか りとなる付加された情報と記銘語間の検索ルートの強さ である。本実験の例でいえば，次のように考えられる。 “ながい”という記銘語を直接検索できない 2 人の被験 者を仮に考えてみる。1人の被験者は“きりんのくびは” という枠組み文（付加された情報）を検索し, も5 1 人 の被験者は “このひもは”という枠組み文を検索したと する。こういう状況では前者の方が記銘語を検索できる 可能性が高いと考えられる。というのは, 前者の枠組み 文の方が記銘語との結びつきが強く, それ故検索ルート がしっかりしているからである。このように, 検索ルー トの強さの違いを仮定すれば, 付加される情報量が等し い場合の記憶成績の差を，検索という側面から説明する ことができるであろう。

\section{実 験 II}

目的 上述の第 2 の実験仮説を検討することを目的と して, 以下に述べる実験が企てられた。
実験計画 $2 \times 3$ の要因計画が用いられた。第 1 の要因 は学年であり, 小学 2 年, 6 年の 2 つ年齢段階を含ん でいた。第 2 の要因は枠組み文の型であり, 交換可能文, 交換不可能文および不適合文という3つの文型を含んで いた。なお, 第 1 の要因は被験者間要因, 第 2 の要因は 被験者内要因である。

被験者 被験者は, 公立小学校の 2 年生 29 名（男子16 名, 女子13名), 6 年生 33 名（男子19名，女子14名）で あり, 平均年齢は 2 年生が 8 歳 3 か月, 6 年生が 12 歳 2 か月であった。

材料 記銘語および再認テストで用いられた語は，実 験 I と同じであった。また，枠組み文も同じものが用い られた。ただし, 実験 I と異なり, 各記銘語は対応寸る枠 組み文とともにスライドにされた。また，再認テストで 用いる語も 1 語ずつスライドにされた。方向づけ課題で 用いるリストは, 実験 I と同じ構成で 2 リストつくられ た。そして, 両リストは, 各学年の男子および女子の被 験者のほぼ半数に割りあてられた。なお, スライド投影 時のスクリーン上の記銘語の 1 文字の大きさは縦横 2.5 $\mathrm{cm}$ であり, 势組み文の 1 文字の大きさは縦横 $1 \mathrm{~cm}$ であ った。また, 再認テストの各語の 1 文字の大きさは縦横 $1.5 \mathrm{~cm}$ であった。スライド投影用のプロジェクターは, Kodak Ektagraphic Slide Projector であった。

手続 実験は偶発学習実験の手続を採用し, 個別的に 実施された。実験場所は, 被験者の所属する小学校の一 室であった。

被験者は，スライドが投影されるスクリーンとの距離 が約 $50 \mathrm{~cm}$ になるように着席させられ，次のような教示 を与えられた。「今から目の前にあるスクリーンに， 1 つの言葉と 1 つの文がでてきます。○○さんはその言葉 を文の空いている所に入れてみて，正しい低なる時に は“注い”，正しい文にならない時には“いいえ”と答え て下さい。わかりましたか。」

教示の後, 2 文字から成る語と対応する枠組み文を含 むスライド 2 枚を用いて練習試行を行った。被験者が教 示の内容を理解したことを確認した後, 本実験に入っ た。1)方向づけ課題試行 上述の教示通り, 被験者はス クリーンの上部に写された語を下の枠組み文に入れた際 の適合性を判断するように求められた。スライドが 1 枚 ずつスクリーンに呈示され, 被験者は各スライドに対し て“はい”もしくは“いいえ”で反応した。なお, 被験 者によって多少反応に要する時間が異なると考えられた ので, 各スライドにつき最低 $5 \mathrm{sec}$. 呈示し, それでも反 
応しない者にはさらに時間を与えた。しかし，どの被験 者も反応するまでに $10 \mathrm{sec}$. 以上は要しなかった。 2) 自 由再生試行 スライド呈示終了後, すぐに「今見せたス ライドに，たくさんの言葉がでてきましたね。どんな言 葉がでてきたか思いだして，順番はどうでもいいですか ら言って下さい。」といら教示を与え， $3 \mathrm{~min}$. 間の口頭 による自由再生テストを行った。ただし, 被験者が枠組 文を再生しようとした場合には,「文の空いている所に 入れた言葉だけでいいですよ。という指示を与えた。 なお, 実験 I と異なり挿入課題を入れず, 直後再生を行 ったのは次の理由による。すなわち, 看護学生を被験者 とした実験 I で比較的偶発再生量が少なかったため, 小 学生ではより再生量が低下し, floor 効果のために関心 のある文型の効果が明確にならない恐れがあると考えた からである。3)再認テスト試行 自由再生テストの後, 普通の再認教示が与えられ再認テストが行れた。再認テ

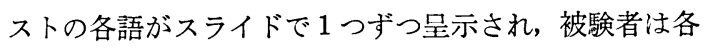
語に対して“あった”もしくは“なかった”で反応した。 再認テスト終了後, 意図的な記憶が生じていなかったか どうかを確認するために「はじめから言葉を覚えようと しませんでしたか。」という質問がなされた。

\section{結 果}

方向づけ課題においては, 誤った反応はなかったので, 実験に参加した被験者は方向つけ課題を適切に行って いるといえる。また, 実験後の内省報告では, すべての被 験者が記憶の意図を持たなかったことが明らかにされた。

正再生率 両学年における枠組み文型ごとの再生率は, FIG.3に示してある。正再生率を角変換して，2（学年）

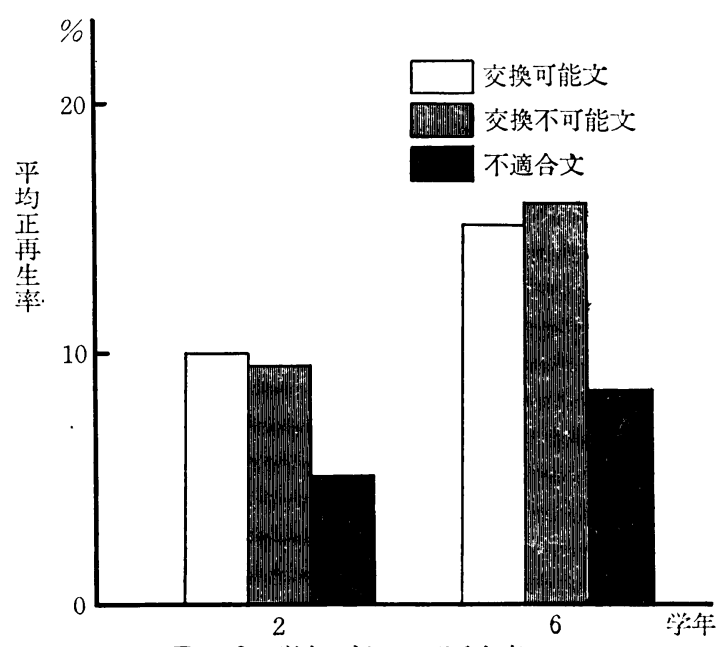

FIG. 3 学年ごとの正再生率
×3 (枠組み文型) の分散分析を行ったところ, 学年の 主効果 $(\mathrm{F}=10.93, \mathrm{df}=1$ と $60, \mathrm{P}<.01)$ が有意であり, 6 年生が 2 年生よりも正再生率が高いことが示された。 また, 枠組み文型の主効果 $(\mathrm{F}=9.41, \mathrm{df}=2$ と $120, \mathrm{P}$ <.01) も有意であったので, Tukey 法による下位検定 を行った。その結果, 交換可能文および交換不可能文を 枠組み文とする記銘語の正再生率が不適合文を枠組み文 とする記銘語のそれよりも高かった（ともに，P<.01） が, 前 2 者間には有意な差はなかった。なお, 学年 $\times$ 枠 組み文型の交互作用は有意でなかった。 $(\mathrm{F}=0.22)$ 。

さらに被験者が方向ゔけ課題において“はい”と反応 した語（模組み文が交换可能文および交換不可能文であ る語）と“いいえ”と反応した語（体組み文が不適合文 である語）の正再生率を比較するために，角変換值を用 いた 2 (学作) $\times 2$ (適合性: はい, いいえ) の分散分析 を行った。その結果, 学年の主効果 $(\mathrm{F}=8.30, \mathrm{df}=1$ と60, $\mathrm{P}<.01)$ とともに, 適合性の主効果 $(\mathrm{F}=30.42$, $\mathrm{df}=1$ こ60, $\mathrm{P}<.01 ）$ も有意であった。このことから， “流いと反応した語の方が“いいえ”と反応した語よ りも, 正再生率の高いことが示された。なお, 学年 $\times$ 適 合性の交互作用柱有意でなかった（ $\mathrm{F}=0.19 ） 。$

虚再認率 再認テストにおいて, 交換可能文を枠組み 文とする記銘語からの連想語に対する虚再認を交換可能 虚再認, 交換不可能文の場合のそれを交換不可能虚再 認，無関連語に対する虚再認を統制虚再認として，それ ぞれの数をカウントした。これらの平均虚再認率は, FIG. 4 に示してある。虚再認率を角変換して, 2 (学年) $\times 3$ (虚再認型) の分散分析を行ったところ, 虚再認型 の主効果 $(\mathrm{F}=7.87, \mathrm{df}=2 と 120, \mathrm{P}<.01)$ のみが有意

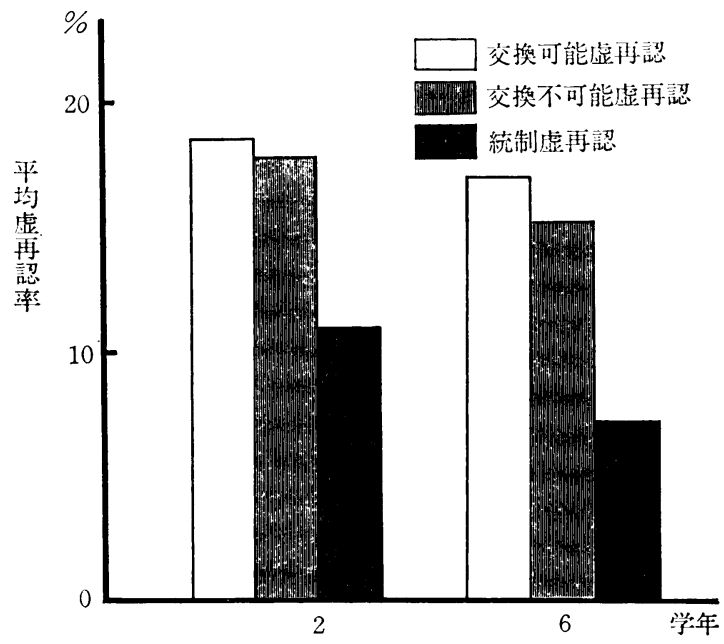

FIG.4 学年ごとの虚再認率 
であった。Tukey 法による下位検定を行ったところ， 交換可能および交換不可能虚再認率が統制虚再認率より も高く（ともに，P<.01）, 前 2 者間には有意な差は 認められなかった。なお，再認テストにおける標的刺激 に対して“あった”と反応した割合，すなわちヒット率 は, 2 年生が $53.4 \%, 6$ 年生が $58.2 \%$ であった。

\section{考察}

実験 II の目的は，第 2 の実験仮説を検討することであ ったが，両学年ともに交換可能文と交換不可能文を枠組 み文とする語の間に成績の差はなく，仮説は支持されな かった。

この理由として考えられることは, 本実験に参加した 6 年生の被験者が文脈をとらえた符号化をしていないと いうことである。それは, 虚再認の分析から明らかにな る。すなわち, 被験者が枠組み文のもつ文脈をとらえて 符号化しているならば，交換可能虚再認が交換不可能虚 再認よりも多くなるはずである。しかし，本実験では両 虚再認の間に差がなかった。意図記憶の手続を用いた先 の研究（豊田, 1984）では, 交換可能虚再認が交換不可 能虚再認よりも多かった。同じ 6 年生の被験者でも, 本 実験は偶発記憶の手続を用いたので, その手続の違いが 結果に反映したのかもしれない。

しかし, 実験 I では偶発事態でも交換可能虚再認が交 換不可能虚再認よりも多かった。そこで, 実験 I と II の 被験者の年齢の違いが注目される。看護学生の方が, 文 脈をとらえて符号化する能力においてより発達した水準 にあると考えられよう。このことを裏づける傍証を得る ために, 実験 I の被験者とは別の看護学生 38 名を用い て, 文脈利用能力に関する補足調查を行った。この補足 調査で汶, 北尾・豊田・広瀬(1983) の読み能力診断検査 の下位㭘査である語識別検査を用いた。この検查は, 綎 方向に配列された，ひらがな文字列の中から名詞を見つ け，できるだけ多くの丸印をつけていくものである。2 つの下位テストに分かれており, テスト 1 は有意味文と なっている文字列, テスト 2 は無意味文になるようにラ ンダムにならべられた文字列から構成されている。テス ト 1 および 2 の検査時間は, ともに 1 分 30 秒である。

丸印の個数を得点として, テスト 1 の得点からテスト 2 の得点を引き, 文脈利用能力得点を算出した。テスト 1 は意味的文脈を含むので, それを含まないテスト 2 に おけるよりも高い得点を示すとすれば，その差が文脈利 用を反映することになる。この得点の算出法は, Word Boundary 課題（文字列の中の語と語の間に区切りを入 れていく溜題）を用いた過去の研究（Klein \& Klein,
1973 ; Klein, Klein, \& Bertino, 1974) と同様である。 算出した得点の平均值は, 13.11 であり, 先の研究（北 尾ら，1983）の 6 年生が3.35であるのに比較すると，か なり大きな値となっている。この検查で測定した文脈利 用能力が本実験での文脈をとらえて符号化する能力と同 じよらに発達するとはいえないが，小学 6 年生の年齢か ら看護学生の年齢までにかなりの能力の発達があると推 察できる。

また，実験 I では 5 段階評定尺度を用いた方向づけ課 題であったので, 実験 II のように単に“はい”“いいえ” で判断する課題よりも文脈に注目した判断を必要とす る。そのために，文脈をしっかりとらえた符号化がなさ れやすかったという可能性も考えられるであろう。

上述したように, 交換可能文および交換不可能文を枠 組み文とする語の再生成績に差はなかったが，ともに不 適合文を枠組み文とする語よりは成績が良かった。これ は, 適合性 (congruity) の効果と呼ばれているもので あり, 従来の研究 (Schulman, 1974; Craik \& Tulving, 1975; Ghatala, Carbonari, \& Bobale, 1980) と一致する。 この適合性の効果は, Craik \& Tulving (1975) によれ ば次のように解釈される。すなわち, 方同ゔけ課題にお いて“はい”と反応した場合に, 記銘語は枠組み文のもつ 文脈の中にうまく当てはまることにより被験者のもつ知 識構造の中一統合 (integrate) される。一方, “いいえ” と判断した場合には統合されない。統合された場合に は, 被験者の知識構造に関連づけた豊富な符号化がなさ れ, その結果記銘語がより精效化されることになるので ある。

\section{結 論}

本研究の結果は, 以下のように要約できる。すなお ち, 文脈をとらえて符号化する能力が十分に発達した看 護学生では, 交換不可能文を枠組み文とする語が交換可 能文を枠組み文とするよりも再生成績が良かった（実験 I )。一方, 文脈をとらえて符号化する能力がまだ十分 に発達していない小学生では, 両枠組み文間に再生成績 の差はなかったのである（実験 II）。

Steinら (1978) は, 大人を被験者とした実験結果から 結論として，（伜組み文のもつ）文脈, 記銘語拉よび被 験者の知識という 3 つの要因の関係を検討することが必 要であると述べている。しかし, 本研究の 2 つの実験結 果から, さらにもら 1 つの要因, すなわち被験者の年齢 を考慮する必要があるといえる。といらのは, 年龄の異 なる被験者間には語をとらえる際の諸能力において発達 差が存在するからである。これらの発達差のうち, 重要 
なものの 1 つとして，文脈をとらえて符号化する能力に おける発達差をあげることができるであろう。それは， この能力が十分に発達していれば枠組み文を効果的に精 緻化に利用できるが，その能力がまだ不十分であれば， いくら良い枠組み文（本研究では交換不可能文）が与え られても精緻化にうまく利用できないと予言できるから である。精緻化を扱った従来の研究では，上述の能力が 十分に発達した大人を被験者とする場合が多く, この能 力には全く注意が払われていなかった。今後, この能力 を考虑していくことは特に精緻化の発達的研究によって 大切なことであろう。

さて, 学校の教授場面では, 教師が学習すべき概念に ついて多様な説明を与える。すなわち，1つの概念につ いて多くの情報を付加するのである。しかし，どんな情 報でもただ数多く与えれば良いというのではない。この ことは, 教師自身が経験的に知っていることであり, 本 研究やSteinら（1978）によって実験的に例証されたの である。では，どんな情報を児童生徒に対して与えれば 良いのであろうか。本研究の結果から言及できること は，学習すべき概念を意味的に限定する情報ということ であろう。Stein らの言葉を借りれば, 児童生徒のもつ 知識の中で学習すべき概念と関連ある部分を明確に示す ような情報でなくてはならないということである。そし て，そのような情報を選択する際に考慮すべきことは， 児童生徒にその情報を十分にこなす能力が備わっている か否かといらことであろう。それ故, 教師は児童生徒の 能力の発達段階に応じて, さらに与えるべき情報を吟味 する必要があるといえよう。

\section{引用文献}

Anderson, J. R. \& Reder, L. M. 1979 An elaborative processing explanation of depth of processing. In Cermak, L.S., \& Craik, F. I. M. (Eds.) Levels of processing in human memory. Hillsdale N. J. : Lawrence Erlbaum Associates.

Craik, F. I. M., \& Lockhart, R. S. 1972 Levels of processing : a framework for memory research. Journal of Verbal learning and Verbal Behavior, 11, 671-684.

Craik, F. I. M., \& Tulving, E. 1975 Depth of processing and the retention of words in episodic memory. Journal of Experimental Psychology: General, 104, 268-293.

Ghatala, E. S., Carbonari, J.P., \& Bobale, L. Z. 1980 Developmental changes in incidental memory as a function of processing level, congruity, and repetition. Journal of Experimental Child Psychology, 29, 74-87.

Hall, J. W. \& Crown, I. 1970 Associative encoding of words in sentences. Journal of Verbal Learning and Verbal Behavior, 9, 303-307.

Hyde, T.S. 1973 Differential effects of effort and type of orienting task on recall and organization of highly associated words. Journal of Experimental Psychology, 97, 111-113.

Hyde, T.S. \& Jenkins, J. J. 1969 Differential effects of incidental tasks on the organization of recall of a list of highly associated words. Journal of Experimental Psychology, 82, 472-481.

Johnson-Laird, P. N., \& Bethell-Fox, C. E. 1978 Memory for question and amounts of processing. Memory \& Cognition, 6, 496-501.

Johnson-Laird, P. N., Gibbs, G.,\& DeMowbray, J. 1978 Meaning, amount of processing, and memory for word. Memory \& Cognition, 6, 372-375.

北尾倫彦 1982 子どもの偶発記憶と処理様式に関する 発達的研究（その 2 ） 日本教育心理学会第24回総 会発表論文集, 264-265.

北尾倫彦・金子由美子 1981 子どもの偶発記憶と処理 様式の効果に関する発達的研究 教育心理学研究 29, 80-84.

北尾倫彦・豊田弘司 - 広瀬雄彦 1983 読み能力の発達 的研究 大阪教育大学紀要 第 N 部門 $32,27-34$.

Klein, G. A. \& Klein, H. A. 1973 Word identification as a function of contextual information. American Journal of Psychology, 86, 339-406.

Klein, H. A., Klein, G. A., \& Bertino, M. 1974 Utilization of contextual information for word identification decisions in children. Journal of Experimental Child Psychology, 17, 79-86.

Kolers, P. A. 1975 Memorial consequences of automatized encoding. Journal of Experimental Psychology: Human Learning and Memory, 1, 689-701.

Schulman, A. L. 1974 Memory for words recently classified. Memory \& Cognition, 2, 47-52.

清水御代明(編) 1980 子どもの連想表- $2 \cdot 4 \cdot 6$ 年生 の第 1 連想反応一 子どもの連想研究会

Stein, B, S., Morris, C. D., \& Bransford, J. D. 1978 Constraints on effective elaboration. Journal of 
Verbal Learning and Verbal Behavior, 17, 707714.

豊田弘司 （1984） 子どもの再認記憶における意味的限

定の発達差 心理学研究 55,117-120.
〈付記>

本研究をまとめるにあたり御指導下さいました大阪教 育大学の北尾倫彦教授に心より御礼申し上げます。また, 実験の助手として御協力いただいた, 光森真由美, 芝池 知子, 松本弘子, 村上奈美樹, 山本多佳子の皆さんに感 謝の意を表します。

(1984年4 月18日受稿)

\section{ABSTRACT \\ EFFECTS OF SEMANTIC CONSTRAINTS OF CONTEXTS ON ELABORATIVE LEARNING IN CHILDREN.}

by

Hiroshi Toyota

Two experiments were carried out to investigate the effects of semantic constraints of sentence contexts on the elaborative learning. In the first experiment 40 subjects (adults) were asked to rate whether the target word would fit into sentence frame with five point scales followed by an unexpected recalland recognition tests. Three types of sentence frame were used:Congruous-Interchangeable(CI), Congruous-Noninterchangeable $(\mathrm{CN})$, and Incongruous(I). The target words fitted into $\mathrm{CI}$ and CN sentence frames, but did not into I sentence frames. In a CI sentence frame, both the target word and its associate fitted sensibly, whereas in a CN sentence frame the target word fitted sensibly but its associate did not. Recall performance was highest in a $\mathrm{CN}$ sentence frame followed a $\mathrm{CI}$ and a I sentence frame. False recognition scores to the associates were higher in $\mathrm{CI}$ sentence frames than in $\mathrm{CN}$ ones. These results were interpreted as showing that effective elaboration seemed to depend on the semantic constraints of sentence contexts embedding the target words.

In the second experiment 29 second and 33 sixth graders were asked to answer orally whether the target word would fit into sentence frame followed by an unexpected recall and reccognition tests. CI and $\mathrm{CN}$ sentence frames led to a better recall than I ones, but the difference between the former two sentence frames was not observed. The difference of frequency of false recognitions to the asociates between $\mathrm{CI}$ and $\mathrm{CN}$ sentence frames was not observed. These results showed that school children would be unable to utilize a $\mathrm{CN}$ sentence frame for effective elaboration of target word. It was suggested that the ability of encoding target words with sentence contexts was critical to effective elaboration. 